\title{
Virtual Migration. Brazilian Diasporic Media and the Reconfigurations of Place and Space
}

Migration virtuelle. Les médias diasporiques brésiliens et les reconfigurations du lieu et de l'espace

Migración virtual. Medios diaspóricos brasileños y la reconfiguración del espacio y el lugar

\section{Martijn Oosterbaan}

\section{(Q) OpenEdition}

\section{Journals}

Electronic version

URL: https://journals.openedition.org/remi/5037

DOI: $10.4000 /$ remi.5037

ISSN: $1777-5418$

\section{Publisher}

Université de Poitiers

\section{Printed version}

Date of publication: 1 February 2010

Number of pages: 81-102

ISBN: 978-2-911627-54-5

ISSN: 0765-0752

\section{Electronic reference}

Martijn Oosterbaan, "Virtual Migration. Brazilian Diasporic Media and the Reconfigurations of Place and Space", Revue européenne des migrations internationales [Online], vol. 26 - n¹ | 2010, Online since 01 February 2013, connection on 15 April 2022. URL: http://journals.openedition.org/remi/5037 ; DOI: https://doi.org/10.4000/remi.5037 


\title{
Virtual Migration. Brazilian Diasporic Media and the Reconfigurations of Place and Space
}

\author{
Martijn OOSTERBAAN*
}

During the first stages of fieldwork among Brazilian migrants in Europe, one of my newfound contacts told me to 'check out his Orkut', to stay in touch. My question what he meant with 'Orkut' was met with considerable astonishment and with his help I quickly learned that Orkut is an online social network site, not unlike Facebook. It was created by Google and named it after its Turkish creator Orkut Büyükkökten. Orkut was launched in January 2004 and quickly became exceptionally popular in Brazil. ${ }^{1}$ Social network sites such as Orkut allow individual members to create a profile of themselves and search for old or new friends who have also joined the site. To my surprise, many of the Brazilians migrants in Amsterdam and Barcelona - the two cities where I did fieldwork - use Orkut as an important resource to organize their migration and daily life at the scene of arrival. Not only in Amsterdam and Barcelona but also in many other European cities where Brazilian migrants live and work, virtual migrant communities (Rheingold, 1993) have sprung up on Orkut. Within these virtual migrant communities people exchange information about a variety of topics concerning their settlement and livelihood in the city and the migrant community sites have also become important podia on which people discuss relevant issues concerning their place and identity as Brazilian migrants in Europe.

This paper ${ }^{2}$ discusses some of the ramifications of the current developments in communication media on the form, content and place of migrant communities in Europe. It is argued that Internet supports both deterritorialization and reterrito-

* Assistant Professor Cultural Anthropology, Utrecht University, Faculty of Social and Behavioural Sciences, Cultural Anthropology, P.O. Box 80140, 3508 TC Utrecht m.oosterbaan@uu.nl

1 http://www.nytimes.com/2007/11/04/technology/04digi.html?_r=1\&ref=business\&oref=slogin, accessed 21-08-2008.

2 The background of this paper is formed by the NWO funded project: 'New Media, Public Sphere and Urban Culture', headed by Prof. Boomkens at the University of Groningen. The research project aims to create a bridge between normative discussions about emerging 
rialization of diasporic Brazilians. Brazilian migrants employ the virtual communities in question to sustain grassroots networks that facilitate migration and settlement in the new locales. The genesis of virtual migrant communities on social network sites has opened up new pathways for community formation and information sharing in and across cities. More than any other medium, social network sites provide the possibility to crosslink migrants to one another in a relatively flat network of communication while they also present new spaces on which to project a symbolic community (Cohen, 1985). These new community spaces on the Internet reproduce and alter existing indications of space and place as migrants identify with multiple localities simultaneously or intermittently, while generally holding on to their Brazilian cultural and/or national background as an important part of their sense of belonging (Hedetoft and Hjort, 2002).

Current digital developments provide a nuance to earlier thoughts on the effects of the Internet 'revolution' on class and mobility. Whereas at the turn of the millennium several scholars argued that ICT technologies would primarily enhance class differences and lead to more segregation between the mobile elite and the immobile poor (Bauman, 1998; Castells, 2000), the rise of virtual migrant communities indicates that certain Internet applications provide an important resource for migrants from different social classes. In general, the development from Web 1.0 to Web 2.0 has shifted the relation between producers and consumers due to the growth of the socalled user generated content and social network sites are arguably part of what Henry Jenkins calls convergence culture (Jenkins 2006). Nevertheless, the digital and physical journeys of the migrants are deeply influenced by state and commercial strategies (de Certeau, 1984). Current Brazilian migration to Europe is thoroughly intertwined with the history and present of state regulation and with the current economic inequalities that sustain and fuel the labor migration from Brazil to Europe. ${ }^{3}$ In practice, a substantial part of the communication between members of the virtual Brazilian migrant communities deals with European legislation, perceived class differences between migrants and the much-debated difference between so-called legal and illegal European residents. Markedly, these juridical categories are both reproduced and criticized in the online discussions.

\section{BRAZILIANS IN WEST-EUROPE}

Research of the International Organization for Migration (IOM) has shown that while the United States remains the most popular destination among Latin American migrants, there has been an increase of Latin American migrants who have

transnational public spheres and empirical discussions concerning new media, community formation and city life. I wish to thank NWO for making this research possible and the project members for their valuable insights. Parts of this paper also appear in a chapter of an edited volume. The chapter focuses on online Brazilian evangelical communities (Oosterbaan forthcoming).

3 See Padilla B. and Peixoto J. (2007) "Latin American Immigration to Southern Europe", Migration Information Source, June 2007.

http://www.migrationinformation.org/Feature/display.cfm?id=609, accessed 05-06-2009. 
come to work and live in Europe in the last decades. ${ }^{4}$ According to the IOM, the current increase can be related to the growing restrictions to enter the USA, especially after 11-9-2001. According to the work of Padilla and Peixoto (see note 3), Spain and Italy had the most legally resident migrants with a Latin American background in 2005, followed by the United Kingdom and Germany. In relation to the other West-European countries, Spain, Italy and Portugal have the highest percentage of Latin American migrants. Not surprisingly, given the language and colonial history of the last three countries Portugal has the most Brazilian born migrants. Nevertheless, in absolute numbers Italy and Spain do not lag far behind. ${ }^{5}$

The overall growth of Brazilian migrants in the South of Europe is matched by the increase in the Netherlands. According to the Dutch department of statistics (CBS) the amount of legal residents with a Brazilian background, rose from 6589 in 1996 to 14823 in $2008 .^{6}$ A large portion of the Brazilian migrants in the Netherlands lives in Amsterdam and Rotterdam. ${ }^{7}$

Numbers of the municipal department of statistics of Amsterdam show that there has been an increase of 67 percent of migrants from Latin America between 1992 and $2006 .{ }^{8}$ Brazilians are specifically mentioned as a group that has grown significantly during the last five years. ${ }^{9}$ Meanwhile, the total population of the city has changed very little. ${ }^{10}$ The municipal department of statistics of Barcelona counted about nine thousand registered Brazilians in the city in the beginning of 2008 against nearly two thousand in 2002. Besides a significant growth of the group of registered Brazilians, the group also has grown in relative comparison with other groups of foreigners. Whereas in 2002, Brazilians comprised 1,7\% of all foreigners, in 2008 this was $3,2 \% .^{11}$ In fact, statistics demonstrate that Brazilians are the fastest growing group of foreigners in Barcelona between 2001 and 2008. ${ }^{12}$ Other fast growing groups include people from Pakistan, Bolivia and China.

4 Migration from Latin America to Europe: Trends and Policy Challenges. International Organization for Migration (2004). http://www.oas.org/atip/atip_Reports.asp, accessed 0506-2009.

5 According to figures presented in Padilla and Peixoto (2007) Spain counted 30.242 'legal' Brazilian migrants, Portugal 49.678 and Italy 26.975.

$6 \mathrm{http}: / /$ statline.cbs.nl/StatWeb/, accessed 18-05-2009.

7 Some say that there are at least as many undocumented as documented Brazilians residing in the Netherlands, but, logically, that is hard to substantiate. The fact is that the amount of forced deportations of undocumented Brazilians from the Netherlands has increased in the past years (see: http://www.parceria.nl/Holanda/20090402-ho-ilegais, accessed 18-05-2009).

8 This does not include Surinamese or Antillean migrants who are treated as a separate category.

9 Statistics show nn increase of 23,77 percent (1489-1843). Besides these documented Brazilians, there are many undocumented Brazilians who work and live in Amsterdam.

10 From 713493 in 1992 to 743027 in 2006. http://www.os.amsterdam.nl/tabel/4370/.

$11 \mathrm{http} / / /$ www.bcn.es/estadistica/angles/dades/inf/pobest/pobest08/part1/t326.htm, accessed 259-2008.

12 http://www.bcn.es/estadistica/angles/dades/inf/pobest/pobest08/part1/t31.htm, accessed 910-2008. 
To the relative growth of documented Brazilians in Europe should be added the plausible growth of undocumented Brazilian migrants. Such an increase is probable if one takes into account the increase of attempted 'illegal' entries into the European Union, the discussions in Brazilian and European media and the amount of undocumented Brazilians I met in the two cities of my research. While in this paper I occasionally refer to 'legal' and 'illegal' migrants, I do so mostly because Brazilian migrants themselves use the term to distinguish between different groups at times. Nevertheless, as De Genova (2002) has forcefully argued, "illegality" (much like citizenship) is a juridical status, that entails a social relation to the state; as such, migrant "illegality" is a preeminently political identity (ibid 422).'

Brazilian citizens are generally allowed to enter the European Union on a tourist visa, yet more and more European countries demand Brazilians to demonstrate upon arrival that they have a return ticket, a place of residence at their destination and enough money to sustain themselves for the period of their stay. Such demands are connected to the concerns of European Union members that too many undocumented people remain within the Schengen associated countries. The European treaties of Schengen and Amsterdam have increased the mobility of citizens of these nations. The treaties have lead to a reduction or abolishment of border checks within the Schengen territory, accompanied by the strengthening of outer border checks. ${ }^{13}$ In February 2007 the pan European organization Frontex, responsible for the development of an integrated program for border security for European Union member states, commenced operation Amazon II, designed to 'tackle illegal migration from South America.' According to the website of Frontex, 29 experts were deployed at 8 European airports: Amsterdam, Barcelona, Frankfurt, Lisbon, Madrid, Milan, Paris, and Rome. 'During the operational phase of Amazon II the total of 2178 South American nationals were refused entry at the airports involved, the biggest groups being the Bolivians, Brazilians and nationals of Paraguay. ${ }^{14}$

While operation Amazon II is labeled an example of an accomplished mission according to Frontex itself, the surveillance of the outer borders of the European Union to control the entrance of non-European citizens has led to conflicts between the Brazilian government and individual European member states. ${ }^{15}$ In February and March 2008 the governments of Spain and Brazil clashed over the treatment of Brazilian tourists entering Spain via the international airport Barajas in Madrid. A Brazilian student traveling to Lisbon was detained at Barajas airport for three days because the authorities doubted her travel motives. The student complained afterwards

13 http://europa.eu/scadplus/leg/en/lvb/133020.htm, accessed 10-10-2008.

14 http://www.frontex.europa.eu/examples_of_accomplished_operati/art10.html, accessed 9-102008.

15 In the summer of 2008 the government of Great Britain proposed to put British policemen at a Brazilian airport to control the inflow of Brazilian migrants to Great Britain before boarding. The minister of foreign affairs of Brazil, Celso Amorim, declared such a mission unacceptable. http://jbonline.terra.com.br/extra/2008/08/15/e150829184.html, accessed 9-102008. 
about the dire treatment during her detention. ${ }^{16}$ On the forth of March, a group of thirty students from Brazil were detained at Barajas for one night for similar reasons and, they also declared they were treated badly by the authorities. ${ }^{17}$ The Brazilian government responded by sending back 7 Spanish citizens who wanted to enter Brazil at the airport of Salvador de Bahia on the $6^{\text {th }}$ of March, claiming they could not prove they had enough money to sustain themselves in Brazil. ${ }^{18}$ The repatriation was generally considered to be an act of retribution. ${ }^{19}$ Reprisal or not, the conflict between Spain and Brazil brought to light the increase in the amount of Brazilians who were denied entrance into Spain but also the difficulties of separating 'tourists' from 'illegal migrants', or, in Zygmunt Bauman's terms, distinguishing 'tourists' from 'vagabonds' (Bauman, 1998: 77-102). ${ }^{20}$

\section{AMSTERDAM AND BARCELONA}

The choice to select Amsterdam and Barcelona as cities of research is related to the increase of South American migrants in Europe but there are also site-specific reasons. Based on the settlement of firms that provide financial and business services (advanced producer services) across the world, Peter J. Taylor and Ben Derudder have argued that Barcelona and Amsterdam are among the nine European cities that are part of 'global urban arenas' (Taylor and Derudder, 2004). ${ }^{21}$ This has some consequences for the theoretical arguments regarding the rise of virtual migrant communities in European cities.

Following recent literature on the transformation of the post-industrial city it is obvious that the boom in transportation and communication technology and the transformation of the global organization of finance and business has drastically changed the social geography of the city. Cities can be seen as hubs in the global network of people, information and goods and are often described as the focal points of two simultaneously occurring processes: denationalization (Sassen 2003) and transnationalization (Hannerz, 1996; Guarnizo and Smith, 1998). Far from implying that national states are becoming obsolete, these processes, amongst other things, indicate that we should be mindful not to assume a neat fit between political citizenries and borders of national states (Fraser, 2007). Subsequently, we should be wary not to fall

16 Sources: Brasil etc. 2(21) April 2008; http://g1.globo.com/Noticias/SaoPaulo/0,, MUL307027-5605,00-NUNCA+TINHA+ME+SENTIDO+TAO+HUMILHADA+DIZ +ESTUDANTE+BARRADA+NA+EUROPA.html, accessed 9-10-2008.

17 http://www.estadao.com.br/cidades/not_cid135450,0.htm, accessed 9-10-2008.

$18 \mathrm{http} / / / w w w 1 . f o l h a . u o l . c o m . b r / f o l h a / c o t i d i a n o /$ ult95u380216.shtml, accessed 9-10-2008.

19 President Lula da Silva of Brazil stated that many Brazilians were held in detention in February and March because of the Spanish parliamentary elections in March. See: http://www1.folha.uol.com.br/folha/cotidiano/ult95u379842.shtml, accessed 9-10-2008.

20 http://www.bbc.co.uk/portuguese/reporterbbc/story/2007/03/070309_barradosemmadrimb_ac.shtml accessed 9-10-2008.

21 The other important (global) European cities are: London, Paris, Frankfurt, Madrid, Zurich, Milan and Brussels (Taylor and Derudder 2004). 
into the trap of 'methodological nationalism', a research methodology that takes the inside-outside/foreigner-native dichotomies as starting points and is thus not adequate to cope with 'the realities of life in a world that is becoming increasingly transnational and involves plural attachments that transcend the boundaries of countries and nationalities. (Beck, 2006: 26). ${ }^{22}$

Especially in cities one experiences the effects of the shifting boundaries, as people form different, crosscutting groups based on ethnicity, class, religion, and lifestyle meet each other in clubs, bars, mosques, churches, associations and so forth (see also Georgiou, 2006: Hannerz, 1996). Recently, Nina Glick Schiller, Ayse "aglar and Thaddeus Guldbrandsen (2006) have argued that researchers of migration (and religion) have often assumed the importance of so-called global cities as pathways for migration and incorporation, without specifying the differences between these and other cities. They suggest that in relation to migrant networks and low wage-labor it is far more useful to 'understand all contemporary cities as global but with different scalar positions (ibid: 615).' While I agree with their critique, in the light of the arguments about the Internet and urban segregation in so called global cities, it is useful to focus on cities that are considered nodes in the global network of finance and information.

In relation to European cities specifically, Manuel Castells has argued that there are three inter-related processes at work in the city, which characterize them as the Informational City, the Global $\mathrm{City}^{23}$ and the Dual City. Much in line which the work of Saskia Sassen (1996), Castells sees the Informational City as the "urban expression of the whole matrix of determination of the Informational Society, as the Industrial City was the spatial expression of the Industrial Society' (Castells, 2000: 13). In accordance with the work of Zygmunt Bauman, who argued that the advent of digital communication enhances social and spatial polarization in the city (Bauman, 1998), Castells argues that we are witnessing the emergence of the Dual City. According to Castells, 'the informational economy has the tendency to generate a polarized occupational structure' (Castells, 2000: 14). In short, Castells argues that urban segregation occurs along the lines of informational capabilities of the population, which is coupled to age, ethnicity and education. Manual labor is downgraded in relation to labor in the information economy and is increasingly carried out by immigrant workers. According to Castells:

22 While I am not totally convinced that Beck's cosmopolitanization approach differs fundamentally from authors who use the term 'globalization' to address the issue of the disappearance of taken-for-granted boundaries and the creation of new, I concur with Beck's urge to strife for a cosmpolitan outlook and a methodology that can include multiple relations between the local, national and global.

23 In Castells' view the Informational City is also a Global City given its position as nodal point in global flows. As Nijman (2000) argues, this does not mean that the world-economy encompass the entire globe. The space of global accumulation is restricted to a small fraction of the earth. Yet, it is precisely at these nodal points, which link global cities to each other, where local and regional economic developments are monitored. 
This leads to the fundamental urban dualism of our time. The one opposing the cosmopolitanism of the elite, living on a daily connection to the whole world (functionally, socially, culturally), to the tribalism of local communities, retrenched in their spaces that they control as their last stand against the macroforces that shape their lives out of their reach. (Ibid)

In this paper I focus on Brazilian migrants at the lower end of the economic spectrum to see how mobility, class and digital communication are related to each other in practice. Based on the general information of the cities and of the Brazilians I have met, certain characteristics of Amsterdam and Barcelona fit part of the description that Castells gives of the urban development in the information economy. A substantial amount of Brazilian migrants comes to Amsterdam with the prospect of becoming cleaners in the houses of the relatively well-to-do inhabitants. In the course of one year I encountered plenty people and talked with them about their life in the Netherlands, their dreams, aspirations and obstacles. In general, I was surprised by the amount of Brazilian women who traveled to Europe by themselves, but this concurs with the findings of Castles and Miller who argue that overall we are witnessing a feminization of migration (Castles and Miller, 2009: 12).

Quite some people arrive without the prospect of receiving a visa and subsequently remain in the Netherlands and in Spain without documents. Substantial amounts of people come to Europe with the idea of earning enough money to be able to 'montar algo em Brasil (to set up something in Brazil).' They want to earn the money to buy some land, to build their own house or to begin a small enterprise. Their idea is to stay in Europe a couple of years, send enough remittances to help or sustain their family in Brazil and save some money as well. Not always do they succeed in saving much nor necessarily do all of them return to Brazil.

In Amsterdam quite some Brazilians are working in the informal sector and are cleaning houses. Since the housing market in Amsterdam is quite tight, most people are sub renting a room or a house, some of them via other Brazilians. House cleaning work is often found via satisfied clients but also by distributing leaflets in middle class neighborhoods or by leaving a notice in one of the fora on Orkut. Clearly there are also many Brazilians who work in other sectors. Among my contacts were artists, entertainers, journalists and business(wo)men, for example. Nevertheless, economic mobility in the Netherlands is tightly bounded by juridical status. It is quite hard to find high-wage employment in the formal economy without the necessary papers. As a consequence, nearly all the Brazilians I met, who have other professions than cleaning, have a working permit. The men and women who do not have such papers generally have few other options than to work as cleaners, handymen or babysitters. While, according to my informants such jobs regularly pay better than the jobs they did in Brazil, many of them had earned their living with skilled labor, working in an office or small (family) bussiness and many would rather have been able to continue their original profession in the Netherlands. In addition, several of the men I spoke found it hard to accept they had to work as cleaners. ${ }^{24}$

24 For an insightful, humorous but often tragic discussion of the fate of Brazilians in the Netherlands from the perspective of a Brazilian migrant see: Impressões de uma Matuta: Aventuras Brasileiras nos Países Baixos (Impressions of a Hilbilly: Brazilian Adventures in the Netherlands), by Kinha Costa. Rio de Janeiro: Letra Capital. 2003. 
Many Brazilians without documents hope to acquire papers in the future. Several migrants I met in Amsterdam tried to obtain or had obtained a passport in one of the Schengen countries on account of the nationality of their (grand)parents, so they could live and work legally in the Netherlands. Italy was one of the countries, which provided several of my Brazilian contacts with such an opportunity. In several interviews people mentioned the possibility of finding a Dutch man or woman to marry and to attain papers. Yet, some women I interviewed remarked they did not come to the Netherlands to simply find any Dutch guy to marry as some Brazilian women did, according to them.

In Barcelona I also met quite some Brazilians who were carrying out manual labor. Many of them were working as cleaners but there were also quite a few who were working as waiters and waitresses. Much more than in Amsterdam, I met Brazilians who were staying in Barcelona with a student visa. The rules and regulations for migration to and residency in Spain differ slightly from other European countries. Quite a number of Brazilians have parents or grandparents who migrated from Spain to Brazil and if one of their parents has the Spanish nationality they can obtain a Spanish passport relatively easy. More than a few Brazilians explained that they came to Barcelona instead of another city because they could earn quite well there, it has a beach and a nice climate and the culture and language are not much unlike in Brazil.

Despite the fact that a portion of the Brazilian migrants earns their income with low-wage labor, the rigid separation between the localized poor and the globalized elite that Castells presents above, does not hold up. Especially in relation to processes of mass migration and developments in the field of communication technologies, such a view is too crude. Almost all the undocumented Brazilians I met in Amsterdam and Barcelona, many of whom were working in low-skilled, low-wage jobs, used their own computer or that of their friend or relative to go online, to download music, to chat with their friends, to check the daily Brazilian news etc. Many of the Brazilians tried to travel to Brazil once every couple of years to visit relatives and plenty of people take the chance to visit other European cities for sight seeing. Most important, many Brazilians from different social backgrounds regularly use the social network site Orkut to communicate with friends, relatives and the people who form part of the virtual communities on Orkut. This is all the more interesting because the genesis of virtual communities in and across cities has been at the center of a debate about the fragmentation and suburbanization of city life.

In general, many urban theorists thought that the development of electronic communication technology would enforce a process of decentralization of the city because it would replace many of the face-to-face relations and the need for physical proximity (De Meyer et al., 1999). Yet, at certain points, even Castells is more optimistic about the possible effects of Internet:

Thus while there are powerful trends pushing towards the fragmentation of the city and the individualization of social relationships, people from all social classes, ethnic, groups, and cultures, build up communities, establish networks of interaction, and recreate urban society from the grassroots... these networks may in fact be expanded and reinforced in the Information Age by the emergence of 
virtual communities around the Internet. Empirical studies document the fact that some of these virtual communities are relatively stable networks of social interaction, and many of them do relate to face-to-face interaction thus bridging the virtual city with urban networks based on personal affinity.

(Castells, 1999: 377-378)

However, as Castells' comments indicate, such a process is not linear, nor certain. Evidence from my research in Amsterdam and Barcelona demonstrates that the so-called non-elite migrants are part of the virtual communities that occasionally support physical gatherings in the city. As I have described elsewhere, several Brazilian evangelical migrant groups use Orkut to sustain communities of congregants who regularly meet face-to-face and communicate online via Orkut (Oosterbaan forthcoming). We should thus be mindful not to approach the question in terms of either fragmentation or centralization of the city, but to understand that virtual communities stimulate new kinds of social relations across space, which are reembedded in the existing routines of every day life. Interestingly, even though Brazilians from different social backgrounds participate in the virtual communities on Orkut, perceived class differences are an important topic of conversation in the online fora of Brazilan migrants, as I will discuss later on in this paper. First, let me introduce Orkut in more detail.

\section{ORKUT}

Orkut was launched in January 2004 and quickly became unevenly popular in Brazil. ${ }^{25}$ ComScore, a company that provides information about Internet has estimated Brazil had the highest percentage of Internet users in Latin America (19.3 million) in $2008 .{ }^{26}$ In June 2007 Orkut had about 24 million unique visitors above the age of fifteen from all over the world. ${ }^{27}$ According to Orkut's own data in May 2009, 49,82 percent of its users were from Brazil, followed by the United States with 20,56 percent and India with 17,56 percent. Pakistan, fourth in rank, only has a share of 0,91 percent. ${ }^{28}$ Due to the popularity and to several legal issues Google has decided to hand over the control of Orkut to Google Brasil in 2008 and leave the development of the social network to Google Brasil and Google India. ${ }^{29}$

Orkut allows every member to add information to his or her individual profile and watch profiles of other people one encounters via friends, communities or the Orkut search engine. Your profile may include photos or videos and it may show your

25 http://www.nytimes.com/2007/11/04/technology/04digi.html?_r=1\&ref=business\&oref=slogin, accessed 21-08-2008.

26 http://www.comscore.com/Press_Events/Press_Releases/2008/06/Top_Latin_America_Web_Sites, accessed 21-05-2009.

27 http://www.comscore.com/Press_Events/Press_Releases/2007/07/Social_Networking_Goes_Global, accessed 21-05-2009.

28 http://www.orkut.com/MembersAll.aspx, accessed 20-05-2009.

29 http://www1.folha.uol.com.br/folha/informatica/ult124u430818.shtml accessed 21-08-2008. 
physical location, for example Barcelona or Amsterdam. One can invite people one finds on Orkut to be your 'friend' and vice versa. Your profile shows how many friends you have. One can also create communities and invite people to become member. Some communities are open to everyone; others only after the moderators have approved membership. The content of some communities is visible to all Orkut members; others are only visible to members of the community in question. One of the popular features of Orkut is the scrapbook on which one can leave messages. ${ }^{30}$ Every member has his/her own scrapbook, which one can make available to all ones friends. You can choose whether you can see who has visited your profile but not without notifying others that you have visited them. Consequently, lurking is only possible when you allow others to track you as well.

During my fieldwork among Brazilians migrants it became clear that Orkut was one of the most popular communication media that Brazilian migrants use to keep in touch with relatives and friends in Brazil and in Europe. People regularly upload photos of their own travels and adventures in the city of settlement, accompanied by comments and descriptions. In addition, people leave each other scraps about their whereabouts and activities but most scraps simply consist of small notes that confirm the friendships between people. In quite a few homes I visited Orkut glowed on screen in the background, while we were talking and having drinks.

In addition to the individual links between people online, quite some people are members of one or more of the many virtual communities on Orkut. The types of communities vary from supporter communities of football teams to fan communities of certain idols or religious communities of specific denominations. Virtual communities on Orkut have at least one moderator, but often more. The moderators are mostly the persons who have created the community and they have the technical possibility (and the power) to allow people to partake in the community or not, to allow non-members to participate or not and to remove messages and members if they wish. In practice, many communities are open to anyone, yet moderators have stated certain guidelines for appropriate online behavior.

While many of these virtual communities support the formation of deterritorialized associations based on identity and life-style rather than location, the virtual migrant communities indicate that this process also has its reterritorializing flipside as Orkut members join communities that are dedicated to (life in) a certain country or a specific city. In the architecture of Orkut a person's place features most prominently on his or her profile and the overview of 'my friends' on Orkut demonstrates rows of friends with only their photo, their name and their place. Consequently, Orkut also functions as a public map with different geographical records.

Many, if not all, Brazilian migrants in Amsterdam and Barcelona put their city of residence on their Orkut profile so as to demonstrate their current place in the world. Interestingly, among them there are plenty who do not merely write one location but

30 One can also send messages to other Orkut members but that option is much less popular. 
insert different places so as to indicate their trajectories; their travels from one place to another (and often back). One of my contacts literally put 'Curitiba para Barcelona' (Curitiba to Barcelona) and another 'rio de janeiro-belgica, rio de janeiro' (Rio de Janeiro-Belgium, Rio de Janeiro). Other people write down their European city of residence but put Brazil as their country, for example 'Barcelona, Catalunya, Brasil'. These and other entries demonstrate that for many migrants the Orkut profile functions as a private/public log of their travels abroad, yet simultaneously as podia to re-affirm their Brazilian nationality as an important part of their identity. This understanding of Orkut comes close to James Clifford's insightful analysis of diaspora discourses, which, according to Clifford, 'reflect the sense of being part of an ongoing transnational network that includes the homeland, not as something simply left behind, but as a place of attachment in a contrapuntal modernity (Clifford, 1994: 311).' Yet, the examples above show that Orkut's architecture allows for new, standardized representations of such an attachment to the homeland, not to mention the recently arisen possibility to form online communities organized on the basis of this attachment.

If one searches for virtual communities in Orkut with the keyword 'Brasileiros em' ('Brazilians in'), the Orkut search engine finds more than a thousand communities. Orkut ranks the communities according to the amount of members of each community. Interestingly, of the first 30 communities, 26 are dedicated to the life of Brazilians in specific cities, 11 of which are located in the US and nine in West-Europe. ${ }^{31}$ The ten leading communities in terms of the number of members are (Brasileiros em) Portugal, Nova York (8.908), Toronto (8.833), Paris (7.658), New York (6.667), Madrid (5.519), Orlando (4.889), Aichi (4.770), Londres (London) (4.690) and Boston (4.213). Notably, among the nine European cities in the top 30 are Paris, Madrid, Milan, London, all cities that form part of the global urban arenas of Taylor and Derudder (2004). The virtual community of Brazilians in Barcelona, which has 8.761 members, would be high in this list of cities were it not that the community in Barcelona goes under the name Brazucas em Barcelona. Brazucas is the common name for Brazilian migrants in the US (see Jouët-Pastré and Braga 2008). A search with the keyword 'Brazuca' shows that there are not as many virtual migrant communities that use this label. The existence of these virtual migrant communities in European cities supports the recent work of Suely Fragoso who encountered many territorial/geographical markers in Orkut's virtual communities in Brazil and argued that under current conditions of vast digital communication across space, geographical place remains an important factor for the construction and sharing of social identity (Fragoso, 2008).

Despite these remarkable results, the amount of members does not tell us everything about the content of or participation in these communities, nor the relations between the online and offline communications. Before we take a closer look at two virtual migrant communities on Orkut, it is worthwhile to discuss the often posed

31 Communities that are dedicated to Brazilians in New York, Los Angeles, London and Madrid feature twice in this list. 
question if the virtual communities on Orkut should be considered 'real communities' since they lack the characteristics of face-to-face contact and one can join them and leave them without much cost or effort.

Here it is important to underscore that the genesis and perseverance of communities are closely related to mass media, as Benedict Anderson (1991) and Arjun Appadurai (1996) have shown. In addition, as the work of Wellman and Gulia (1999) aptly shows, it makes little sense to understand virtual communities as substitutes or replacements of the 'real' thing. 'The Net is the Net' (ibid: 16) and evidence suggest that virtual communities can support strong and lasting ties between people who may or may not meet each other face-to-face regularly and/or support a multitude of relatively weak links that are nevertheless very meaningful for the participants in question. In the words of Wellman and Gulia, those who worry that a virtual community is not a real community are 'mistaking the pastoralist myth of community for the reality' (ibid: 17). Likewise, as Myria Georgiou states in relation to diaspora and identity in the city: 'media suggest new ways of shaping belonging, beyond conventional restrictions between the real and the virtual...'(Georgiou 2006: 12). Lastly, we should take into account that in general the constitution of contemporary urban communities relies heavily upon technological mediation, as Ash Amin and Nigel Thrift convincingly argue (Amin and Thrift, 2002: 41-48). Thus, instead of asking how 'real' virtual communities are, one could better inquire what role virtual migrant communities play in relation to face-to-face gatherings and other mass media. To give some preliminary answers to these questions I compare several Orkut communities that Brazilian migrants in Amsterdam and Barcelona use.

\section{BRASILEIROS NA HOLANDA AND BRAZUCAS EM BARCELONA}

One of the popular communities on Orkut among Brazilians in Amsterdam is the community Brasileiros na Holanda. As the label suggests, the community is not specifically meant for Brazilians in Amsterdam, though many regular participants live in Amsterdam. When I started the research in 2007 the community had about 1800 members and one year later it had almost 2200 members. In May 2009 the community had 2512 members.

The community site offers information about upcoming events, polls and a forum featuring many different topics concerning life in the Netherlands. Orkut communities allow members to post messages visible on the community page. One can post upcoming events, initiate a poll or start a topic in the forum. Especially the last application is quite popular in some of the Orkut communities since the forum allows members to discuss certain specific topics with one another over a period of time. The topics posted on the fora vary and there are many topics that concern jokes or questions where one can encounter specific things, such as Brazilian products or food.

Topics that receive many entries from various members are the ones that concern the situation in which Brazilians find themselves. In the community Brasileiros na Holanda much effort has been put in the categorization of certain topics 
that are of frequent concern. The moderator has wisely created a topic in the forum under the title FAQ (frequently asked questions), which includes common topics such as 'Estudar Holandes (study Dutch),' 'Mandar Dinheiro para o Brasil (Send money to Brasil),' or 'Emprego (Work).' The messages in the topic FAQ consist of links to other topics in the forum. Besides the explicit request to search in the FAQ before posting a new topic in the forum, during discussions people are recurrently advised to search for former entries concerning these and other topics so as to avoid limitless and often inefficient repetition.

While much could be said about it, in this paper I will not so much focus on the social dynamic of the virtual community itself. The creator of the community is also the moderator (who lives in Portugal) and she has created certain rules for the community. All communication should be in Portuguese and the topics have to be related to the Netherlands, for example. The moderator has the privilege to delete topics that are not of concern to the community and the privilege to expel people who use fake profiles or are harassing others. While, theoretically the moderator has almost absolute power, the community only functions well when many people remain member and participate and if people find the moderator too authoritarian they can simply stop frequenting the community. Though harassing is not allowed, the norms and values of the community are mostly in the hands of the members. Discussions about such norms lead to an interesting form of self-governance.

Besides the topics that concern the practical problems and solutions of day-today life in the Netherlands, Brasileiros na Holanda is the place where many of the discussions concerning migration, documents and rights are held. Some of the topics that return frequently concern the changes in European and Dutch legislation and implementation of visa applications, naturalization procedures, residency permits etc. The legislation is far from easy. There are different kinds of permits but also different possibilities to reside in the European union legally. Fact of the matter is that many people reside in the Netherlands without a permit and many Brazilians have been sent back after being 'caught' without the necessary documents at airports or in the streets of different European cities. News or questions about such events are often posted and discussed. The topic 'Ilegal', for example, started in 2006 and remained quite popular until the end of 2008. In this long lasting discussion members express different opinions about the reasons and consequences for residing and working in the Netherlands (and elsewhere) without a permit. Occasionally, similar discussions appear under other topics in the forum. For example, the discussion under the topic 'Procurase Au-Pair' (Au-Pair Wanted), which emerged in 2009 showed that some Brazilians with documents were unaware of the realities of their undocumented compatriots until the latter also joined the discussion.

Discussions also often involve the experiences of members who have migrated to the Netherlands. Some people feel homesick or have troubles getting accustomed to Dutch habits and customs. Some people who have migrated a while ago express their worries if they can ever adapt themselves to life in the Netherlands or in Brazil. Others react fiercely to Dutch discussions concerning the place and status of so-called foreigners in the Netherlands. One of my contacts, Dona Dora was a frequent parti- 
cipant in discussions in 2007. Since she has been living in the Netherlands for twenty years, she has something to say about all these subjects, although I think her favorite topic is Brazilian cuisine and finding the essential ingredients in Amsterdam. In an online discussion about passports that had more than hundred entries and went on for about a year, one of the central questions was if one has to give up one's Brazilian nationality to get a Dutch passport. Dona Dora responded:

My God, I have double nationality since years and when I applied I had to say it loud and clear 'I WANT DOUBLE NATIONALITY', many did not ask it and they lost their Brazilian passport... I have been living in Holland for twenty years and if they would have asked me then to give up my Brazilian nationality I would not have done it... Severe patriotism, love for the patria, I don't know what it is,

I would not exchange it... In the country of OTHERS you always remain a foreigner and in Holland it is worse, you are an 'Allochtoon' the ugliest name I heard in all my life.

While it is but one example, the entry is indicative of the ongoing discussions in the Netherlands about the common description of non-Western citizens as allochtonen (allochthonous citizens) and the oppressive power of classification that many migrants experience. ${ }^{32}$ Far from being a neutral term, in practice allochtonen is tightly bound up with a process that Yen Le Espiritu has described as 'differential inclusion' (Espiritu 2003: 47). The continuous description of people with different national backgrounds, cultural heritages and/or religious affiliations as citizens that are not (yet) fully part of Dutch society reproduces the sense that one will 'always remain a foreigner', as Dona Dora fittingly describes. Nevertheless, as the discussions between Dona Dora and others also indicate, the forum is also a site where people confirm their wish to live in the Netherlands without being forced to give up their Brazilian identity.

The forum in Brasileiros na Holanda also functions as a relay for news about Brazilians in the Netherlands and consequently as a site where the sense of community can be reproduced (albeit not without struggles). In 2008 a bus full of Brazilians was stopped by the marechaussee ${ }^{33}$ after passing the border between Belgium and the Netherlands on its way back from Paris. A passport check revealed that some of the Brazilians had been residing in the Netherlands without the appropriate documents and 32 of the 45 passengers where arrested. Quickly after it had happened, a member of the community posted the news on Orkut, asking the participants for help to locate a friend who supposedly was on the bus. Several people reacted because they thought they knew people on the bus and others reacted with astonishment that there apparently were these kinds of border checks within Europe. The next day the first hyperlink appeared to the online version of the Dutch newspaper Algemeen Dagblad, which stated that the passengers had traveled to Paris in the light of the visit of Pope

32 See for example Peter Geschiere's contribution in the Dutch independent weekly news magazine De Groene Amsterdammer, 28 August 2009. Year 133, no 35.

33 The royal marechaussee is a branch of the Dutch ministery of defense, responsible for the control of persons at the Dutch borders. 
Benedictus XVI to France. ${ }^{34}$ Some confusion arose when another link appeared to BBC Brasil a day later, which said the Brazilians had been to Disneyland (and not the Pope). ${ }^{35}$

In between the updates of the whereabouts and situation of the detainees - who were brought to a detention center in Rotterdam where they were assisted by a Brazilian pastor from Amsterdam - heated discussions started about the Brazilians in the Netherlands. When one member criticized another on account of a language mistake, the solidarity between Brazilians in the country was questioned and the discussion focused on the perceived internal rifts in the community. One member accused others of being too sensitive; another called someone a racist because she had made a remark about the physical differences between Brazilians. In reaction, several pleaded to have discussions about genuinely important topics instead of concentrating on the question who was better or worse. The discussion ended with the entry of a member who urged people to lighten up. According to him, they were all migrants in the end. Legal or illegal, blond or black, the community should benefit all. The recurring efforts to discuss the state of affairs of the Brazilians in the Netherlands - this instance set off by concerns about the bus passengers - marks the commitment to this online community but the discussion also shows that Brazilians in the virtual community often apply the juridical difference between legal and illegal themselves.

Besides Brasileiros na Holanda, there are also several Orkut communities that are specifically related to the city of Amsterdam, for example Eu morro em Amsterdam and Amsterdam-Brasil. The latter was never as popular as Brasileiros na Holanda but since 2008 the amount of discussions on the forum increased as well as the amount of participants. Apart from the online encounters members of the virtual migrant communities occasionally organize meetings in the city. Such a meeting is called an Orkontro, a conjunction of the words Orkut and encontro (meeting). Interestingly, many of the Orkontros in the Netherlands are held in Amsterdam. During the Orkontro in which I participated, people held lively conversations about the city and they gossiped about other people on Orkut. Such offline talk about online others indicated once more that virtual and face-to-face realities often merge into one another.

The Orkut community that was best known among Brazilian migrants in Barcelona is Brazucas em Barcelona. The community exists since 14 June 2004. At the first of September 2008 the community had about 8.600 members and in June 2009 8.750. Similar to its Dutch counterpart it offers many topics in the forum of which a large portion deals with finding the right places and possibilities to work and live in Barcelona. The language is Portuguese. Several of my Brazilian contacts in Barcelona declared that especially in the period after their arrival to the city Brazucas em Barcelona had proven to be of help to get settled. There is also a community on Orkut

34 http://www.ad.nl/binnenland/2610225/Brazilianen_uitgezet_na_bezoek_aan_de_paus.html, accessed 01-06-2009.

35 http://noticias.uol.com.br/bbc/reporter/2008/09/17/ult4909u5625.jhtm, accessed 01-06-2009. 
that is called Brasileiros na Espanha, which had about 18.700 members on the first of September 2008. This community resembles the community for Brazilians in Barcelona and it is clear that people are often members of both.

While they deal with generally the same organizational problems Brazucas em Barcelona is organized a little different from its Dutch counterpart. One of the two moderators has created a list of 'official topics' in the event calendar which is shown on the community page, to be able to lead people to the discussions that deal with the most important themes for Brazilian migrants: work, houses, food, etcetera. By posting it as an event in 2009 , it will appear for a while on the first page and people do not have to stroll through different topics in the forum endlessly. In an interview I held with one of the moderators, he told me that it took him a while to get the community relatively organized and that one of the biggest problems was the amount of 'fakes' he had to remove. Fakes are people who create an Orkut profile with an invented name or the name of someone else. According to the moderator, when he encounters a fake he warns him or her that he or she will be removed if they cannot explain why they do not use their real name. He does take into regard the kind of participation of the fake. If people are always participating positively yet want to remain anonymous he is willing to be more lenient.

According to the moderator, the 'culture' of the community also changed for the better. At first there was a good deal of animosity between members but nowadays there is more patience and he also tries to give a better example himself. 'We have to take care of this community, there are so many useless communities on Orkut,' he exclaimed. To him it is important because the community also serves as a means of communication between old and new migrants, which helps the latter to find their way in the city easier and faster. According to him the 'Amigos do Brasil de Barcelona' is not very helpful in that respect, though they organize many parties. Likewise, in his opinion the consulate does more for Spanish people who travel to Brazil than the other way around. One of the recurring rifts in the community is caused by the perceived class differences, which is related to the regional and ethnic background of the participants and possession of documents. Some people say that the Brazilians 'with papers' think that they are better than the rest and that makes it hard to have a discussion about the people that reside in Barcelona without a permit. According to a Brazilian woman who participated much in Brasileiros na Holanda in the onset, class differences and class conflicts played a significant part in the communication between members and the 'legality' of the members was a recurring topic of conversation.

To give a recent example, during my searches in the fora of the two communities I encountered one Brazilian woman, living in the Netherlands who was engaged in a discussion about illegal work in both communities. In both the discussions she complained about the amount of Brazilians that were living in Europe without papers and in both discussions people reacted to her statements. In the Brasileiros na Holanda forum, someone simply stated that the majority of the 'illegals' are 'legais' (legals) - in Brazil the word legal (legal) is also used for something cool - to emphasize that juridical status says nothing about a persons character. In the Brazucas em Barcelona forum many discussants replied that having a passport did not make her a better person 
than others and that her very entry proved this point. There was even someone who created a fake to curse the Brazilian/Dutch woman but that person was called a coward by one of the discussants.

These examples indicate that the virtual communities function as places where the status of Brazilian migrants can be discussed and where attempts are made to unravel juridical categories from moral judgments, class differences and socio-cultural stigmas. Nevertheless, the examples also show that these juridical categories have real consequences and that they are both reproduced and criticized amongst Brazilians themselves.

\section{CONCLUSION: MIGRATION, SPACE AND MEDIA}

The surge of new fora where migrants discuss their position in Europe or their country of residence directs our attention to the fact that we have to think about the changing places of ethnographic research in a time of mass migration and digital media. Despite the acceptance that the ethnographic object is neither particularly local nor global and that we might have to practice 'multi-locale ethnography', as George Marcus has proposed (Marcus 1986: 171), the ethnographic tradition maintains a certain preference for a bounded space, a particular place from which one can start to 'construct the text' (ibid: 172). Marcus, for example compares a multi-locale ethnography to a 'second, much more manageable mode', in which 'the ethnographer constructs the text around a strategically selected locale, treating the system as background, albeit without losing sight of the fact that it is integrally constitutive of cultural life within the bounded subject matter (ibid).' On the one hand, one could say that my choice to do fieldwork in Amsterdam and Barcelona followed such logic. On the other hand, what if 'the subject matter' is located in several Brazilian places, Amsterdam and Barcelona, simultaneously and, moreover, what if social network sites are conceived as places as well?

This methodological problem is related to what Marianne Franklin has described as the 'shifting fields' of ethnographic research. ${ }^{36}$ According to her, the burgeoning of virtual fields of research whose realities intersect with classical fieldwork sites has reminded us that every 'field' is porous instead of hermetic. To understand the relations between them, she argues, we need to go beyond the virtual/ real dichotomy and adopt a dialectal research praxis that allows us to see and discuss how different fields are related without reducing one to the other. Here I would like to add that such shifting concerns both ethnographers and informants in a dialectic fashion. Migrants produce online and offline places for themselves and these places affect each other in multiple ways. In order to come to terms with these shifting fields we might best practice a form of ethnography that is virtual and multi-sited. While I

36 Franklin (2007) 'Contiguities \& Contingencies with/in Cyberspace: Shifting Fields' Working paper presented at the Virtual Etnography \& Co. workshop hosted by the Virtual Knowledge Studio (KNAW) 22-7-2007. http://vksethno.wordpress.com/category/working-papers/. 
thus largely agree with Christine Hine who has argued that: 'The challenge of virtual ethnography is to explore the making of boundaries and the making of connections, especially between the "virtual" and the "real" (Hine 2000: 64) and "[T] he investigation of the making and remaking of space through mediated interactions is a major opportunity for the ethnographic approach' (ibid.), I am not sure if I agree with her remark that: 'The growth of mediated interaction renders it unnecessary for ethnography to be thought of as located in particular places, or even as multi-sited' (ibid). The rise of virtual migrant communities on Orkut dedicated to life in particular cities indicates that physical places are important starting points for migrants to establish new connections and that we gain insight into systemic patterns of deterritorialization and reterritorialization when we practice ethnography at multiple locations. By studying both offline and online worlds of migrants we gain insight in the ways in which actors contest and produce locality amidst and through the cultural flows (Appadurai, 1996; Gille and Ó Riain, 2002), using social network sites that were not necessarily developed for that reason.

Despite my focus on the surge of social network sites here, I also contend that we should place new communication media within the wider spectrum of mediations that affect people. As William Mazzarela has forcefully argued, anthropologist rarely acknowledge that mediation "precedes what we commonly recognize as "media"; that, in fact, local worlds are necessarily already the outcome of more or less stable, more or less local social technologies of mediation (Mazzarella, 2004: 353). Studying only one medium of communication that certain migrants use - often the 'newest in town' directs our attention to possible new circuits of communication, community formation and emergent transnational public spheres, yet may blind us from the obvious fact that people use different media, which each have their own logic and space of interaction and phenomenological implications. Television can offer its viewers different nationalsubject positions, depending on the accessibility of cable and/or satellite, yet films arguably form a different genre with different implications for the establishment of a shared cultural style.

Moreover, each medium has not one, but different relations to local, translocal, transnational and global flows of information and therefore the question what the development and access to a medium might mean to the existence of diasporic public spheres should be specified per instance. For example, between 1992 and 2009, a group of dedicated Brazilians published the bilingual Brazilian/Dutch magazine Sem Fronteiras (Without Borders) to which people could subscribe. ${ }^{37}$ The magazine appeared once every two months and featured the same news articles in Dutch and in Portuguese. As the title suggests - and was confirmed in an interview with the editorin-chief (2006-2009) - the magazine aimed to overcome the boundaries between Dutch and Portuguese reading publics by providing news that was thought to be interesting to

37 The magazine Sem Fronteiras had an edition of 10.000 printed copies and cost about five euros. Between 1992 and 2006 the magazine was titled Papagaio. 
Brazilians in the Netherlands and to Dutch people in Brazil. Since it was situated between two national communities, the magazine could thus not be categorized as exclusively Brazilian or Dutch.

In Barcelona I encountered only Brazilian magazines that were entirely in Portuguese, such as the freely distributed magazine Brazilcomz. ${ }^{38}$ While both Brazilcomz and Sem Fronteiras magazines could be labeled as diasporic media, they are distributed differently and have different (national) publics in mind. Nevertheless, both in these magazines and in the European-Brazilian magazine Brasil Etc ${ }^{39}$ that also circulates in Amsterdam and Barcelona, migration and legislation are frequently discussed. Tellingly, Brasil Etc also has its own community on Orkut with links to its website. While this is not the place to discuss the content and circulation at length, the remediation of information for Brazilian migrants between Orkut and magazines such as Brasil Etc indicates not only that new and old media are colliding but also that social network sites such as Orkut are likely to become important nodes in the networks that form contemporary diasporic public spheres.

\section{References}

AMIN Ash and THRIFT Nigel (2002) Cities: Reimagining the Urban, Cambridge, Polity Press. ANDERSON Benedict (1991 [1983]) Imagined Communities. Reflections on the Origen and Spread of Nationalism, London, Verso.

APPADURAI Arjun (1996) Modernity at Large. Cultural Dimensions of Globalization, Minneapolis, University of Minnesota Press.

BAUMAN Zygmunt (1998) Globalization: The Human Consequences, Cambridge, Polity Press. BECK Ulrich (2006) Cosmopolitan Vision, Cambridge, Polity Press.

CASTELLS Manuel (1997) The Power of Identity, Oxford, Blackwell Publishing.

CASTELLS Manuel (1999) 'The culture of cities in the information age', in Susser, I. (2002) The Castells Reader on Cities and Social Theory, Oxford, Blackwell Publishing.

CASTELLS Manuel (2000) 'European cities, the informational society and the global economy', in Deben, L., W Heinemeijer and D. van der Vaart (eds), Understanding Amsterdam: essays on economic vitality, city life and urban form, Amsterdam, Spinhuis.

CASTLES, Stephen, MILLER Mark J. (2009) The Age of Migration. International Population Movements in the Modern World, Palgrave Macmillan.

CLIFFORD James (1994) Diasporas, Cultural Anthropology, 9(3), pp.302-338.

COHEN Anthony P. (1985) The Symbolic Construction of Community. London: Routledge.

DE CERTEAU Michel (1984) The Practice of Everyday Life. Berkeley, University of California Press.

DE GENOVA Nicolas (2002) Migrant "illegality" and deportability in everyday life, Annual Review of Anthropology, 31, pp.419-447.

38 Brazilcomz comes out twice a month and according to its own website has a distribution of 10.000 per issue. See: http://www.revistabcz.com, accessed 4-6-2009.

39 Brasil Etc was launched in 2006 and is written in Portuguese. See: http://www.brasiletc.co.uk/, accessed 5-06-2009. 
DE MEYER et al. (eds.) (1999) The Urban Condition: Space, Community, and Self in the Contemporary Metropolis, Rotterdam, 010 Publishers.

ESPIRITU Yen Le (2003) Home Bound. Filipino American Lives across Cultures Communities and Countries, Berkeley, University of California Press.

FRAGOSO Suely (2008) Conectibilidade e geografia em sites de rede social: um olhar sobre as relações entre território e identidade e a permeabilidade on-line/off-line a partir do Orkut, Revista Galáxia, 16, pp.109-121.

FRASER Nancy (2007) 'Transnationalizing the public sphere: on the legitimacy and efficacy of public opinion in a post Westphalian world', in Benhabib Seyla, Shapiro I., Petranovich D. (eds.) Identities, Affiliations, and Allegiances, Cambridge, Cambridge University Press.

GEORGIOU Myria (2006) Diaspora, Identity and the Media. Diasporic Transnationalism and Mediated Spatialities, Creskill, NJ, Hampton Press.

GILLE Zsuzsa, Ó RIAIN Sean (2002) Global Ethnography. Annual Review of Sociology, 28, pp.271-295.

GUARNIZO Luis Eduardo, SMITH Michael Peter (1998) Transnationalism from Below (Comparative Urban and Community Research), London, Transaction Publishers.

HANNERZ Ulf (1996) Transnational Connections: Culture, People, Places, London, Routledge.

HARVEY David (1990). The Condition of Postmodernity: An Enquiry into the Origins of Cultural Change, Cambridge, Blackwell.

HEDETOFT Ulf, Mette HJORT (2002) The Postnational Self. Belonging and Identity, Minneapolis, University of Minnesota Press.

HINE Christine (2000) Virtual Ethnography, London, Sage.

JENKINS Henry (2006) Convergence Culture: Where Old and New Media Collide, New York, New York University Press.

JOUËT-PASTRÉ Clémence, BRAGA Leticia (2008) Becoming Brazuca. Brazilian Immigration to the United States, Cambridge, David Rockefeller Center for Latin American Studies, Harvard University. Distributed by Harvard University Press.

MARCUS George E. (1986) 'Contemporary Problems of Ethnography in the Modern World System', in James Clifford and George E. Marcus, Writing Culture: The Poetics and Politics of Ethnography, Berkeley, University of California Press.

MAZZARELLA William (2004) Culture, Globalization, Mediation, Annual Review of Anthropology, 33, pp.345-367.

NIJMAN Jan (2000) 'The global moment in urban evolution', in Deben, L., W Heinemeijer and D. van der Vaart (eds), Understanding Amsterdam: essays on economic vitality, city life and urban form, Amsterdam, Spinhuis.

RHEINGOLD Howard (1993) The Virtual Community. Homesteading on the Electronic Frontier, Reading, Addison-Wesley.

SASSEN Saskia (1996) Losing control? Sovereignty in An Age of Globalization, New York, Columbia University Press.

SASSEN Saskia (2001) The Global City: New York, London, Tokyo, Princeton University Press.

SASSEN Saskia (2003) 'Globalization or denationalization?', Review of International Political Economy, 10(1), pp.1-22.

SCHILLER Nina Glick, Ayse "AGLAR and Thaddeus GULBRANDSEN (2006) 'Beyond the Ethnic Lens: Locality, globality, and born-again incorporation', American Ethnologist 33(4), pp.612-633.

TAYLOR Peter J., DERUDDER Ben (2004) 'Porous Europe: European cities in global urban arenas', Tijdschrift voor Economische en Sociale Geografie, 95(5), pp.527-538.

WELLMAN Barry, GULIA Milena (1999) 'Virtual Communities as Communities: Net Surfers Don't Ride Alone.', in B. Wellman (ed.) Networks in the global village, Boulder, CO, Westview. 


\title{
Migration virtuelle. Les médias diasporiques brésiliens et les reconfigurations du lieu et de l'espace
}

\author{
Martijn OOSTERBAAN
}

Cet article examine les implications de l'évolution actuelle des moyens de communication sur la forme, le contenu et la place des communautés brésiliennes migrantes en Europe. Il entend montrer que l'Internet permet à la fois la déterritorialisation et la reterritorialisation des diasporés brésiliens à Amsterdam et à Barcelone. Les migrants brésiliens utilisent les communautés virtuelles sur les sites des réseaux sociaux pour maintenir des réseaux de connaissance qui facilitent la migration et l'installation dans les villes de destination. L'essor des communautés virtuelles migrantes sur les sites de réseaux sociaux ouvre de nouvelles voies pour la construction communautaire et le partage d'informations dans et entre les villes, en même temps qu'il contribue à la formation d'une sphère publique brésilienne diasporique. Les sites de réseaux sociaux offrent la possibilité d'interconnecter les migrants les uns aux autres dans un schéma relativement plat de communication, et présentent également de nouveaux espaces sur lesquels projeter une communauté symbolique. Ces nouveaux espaces communautaires sur Internet interrogent les notions d'espace et de lieu dans la mesure où les migrants s'identifient à des localités multiples, simultanément ou de façon intermittente, tout en faisant de leur héritage culturel et/ou national brésilien une part importante de leur sentiment d'appartenance.

\section{Virtual Migration. Brazilian Diasporic Media and the Reconfigurations of Place and Space}

\author{
Martijn OOSTERBAAN
}

This paper discusses the implications of the current developments in communication media on the form, content and place of Brazilian migrant communities in Europe. It is argued that Internet supports both deterritorialization and reterritorialization of diasporic Brazilians in Amsterdam and Barcelona. Brazilian migrants employ virtual communities on social network sites to sustain grassroots networks that facilitate migration and settlement in the cities of destination. The rise of virtual migrant communities on social network sites opens up new pathways for community formation and information sharing in and across cities and contributes to the formation of a Brazilian diasporic public sphere. Social network sites provide the possibility to crosslink migrants to one another in a relatively flat network of communication while they also present new spaces on which to project a symbolic community. These new community spaces on the Internet reproduce and alter existing indications of space and place as migrants identify with multiple localities simultaneously or intermittently, while generally holding on to their Brazilian cultural and/or national background as an important part of their sense of belonging. 


\section{Migración virtual. Medios diaspóricos brasileños y la reconfiguración del espacio y el lugar}

\section{Martijn OOSTERBAAN}

Este artículo discute las implicaciones que tiene el desarrollo de los medios de comunicación en la forma, el contenido y el lugar de las comunidades de migrantes brasileños en Europa. Se argumenta que Internet apoya la deterritorialización y la reterritorialización de los migrantes brasileños en Ámsterdam y Barcelona. Los migrantes brasileños emplean las comunidades virtuales de los sitios online de redes sociales para mantener redes de base que facilitan la migración y el asentamiento en las ciudades de destino. De esta manera el surgimiento de estas comunidades virtuales de migrantes en los sitios online de redes sociales abre nuevas vías para la construcción de comunidades y el intercambio de información tanto dentro de las ciudades como entre ellas al tiempo que contribuye a la formación de una esfera pública diaspórica brasileña. Las redes sociales online ofrecen la posibilidad de que los migrantes se vinculen unos a otros en una red de comunicación relativamente horizontal al mismo tiempo que constituyen un nuevo espacio donde se proyecta una comunidad simbólica. Estos nuevos espacios comunitarios en Internet reproducen y transforman los indicadores de espacio y de lugar existentes ya que los migrantes se identifican con múltiples localidades simultáneamente o de manera intermitente, mientas preservan al mismo tiempo su identidad nacional y cultural brasileña como una parte importante de su sentido de pertenencia. 